\title{
Can mouth washes containing chlorhexidine $0.12 \%$ be used as synonym of a water solution of chlorhexidine $0.12 \%$ ?
}

\author{
Ivana Barbosa Suffredini, ${ }^{1, *}$, Cintia Helena Coury Saraceni², Ingrit Elida Collantes Díaz ${ }^{1}$
}

${ }^{1}$ Center for Research in Biodiversity, Extraction Laboratory, Paulista University, São Paulo, SP, Brazil, ${ }^{2}$ School of Dentistry, Graduate Program in Dentistry, Paulista University, São Paulo, SP, Brazil

\begin{abstract}
Chlorhexidine digluconate $(\mathrm{CHX})$ is a gold standard drug in dentistry and is widely used as a reference in both in vitro and in vivo experiments. Due to ease of access, mouth washes containing CHX $0.12 \%$ are used as a substitute for aqueous CHX $0.12 \%$ solution in laboratory experiments. Additionally, it is well known that for product flavor purposes, volatile compounds are added to mouth washes formulations. Volatiles added to CHX $0.12 \%$ may improve wash's antibacterial ability. Volatiles add potency to the mouth wash formulation. Compared with an aqueous CHX $0.12 \%$ solution, it is proposed that CHX solutions and Periogard ${ }^{\circledR}$ would have antimicrobial activity. Antimicrobial activity was assessed in the present study via disk diffusion assays against Streptococcus mutans, Streptococcus sanguinis and Escherichia coli. Periogard ${ }^{\circledR}$ showed a significantly higher antibacterial activity in relation to CHX 0.12\% $(\mathrm{p}<0.05)$ and a similar activity in relation to CHX 1\% $(\mathrm{p}>0.05)$. Periogard ${ }^{\circledR}$ volatiles were analyzed by gas-chromatography/mass spectrometry (GCMS) and the presence of antibacterial menthol, menthone, isomenthol, menthyl acetate, trans-anethol and eugenol was verified. Finally, the use of Periogard ${ }^{\circledR}$ as a synonym of CHX $0.12 \%$ must be avoided, because its antibacterial activity is closely related to CHX $1 \%$.
\end{abstract}

Uniterms: Mouth washes/evaluation. Periogard ${ }^{\circledR}$. Chlorhexidine. Antimicrobials/mouth use/evaluation.

Gluconato de clorexidina (CHX) é um fármaco considerado padrão ouro, em Odontologia, amplamente usado como referência em estudos in vitro e in vivo. Em razão da facilidade de acesso, enxaguatórios bucais que contêm CHX 0,12\% são usados em substituição à solução aquosa de clorexidina (CHX 0,12\%), em experimentos laboratoriais. É sabido que devido à palatabilidade do produto, os mesmos enxaguatórios bucais contêm compostos voláteis em sua formulação, além da CHX $0.12 \%$. Visto que voláteis adicionados podem acrescentar poder antibacteriano à formulação, a comparação da resposta antibacteriana da solução aquosa de CHX em diferentes concentrações e de Periogard ${ }^{\circledR}$ é proposta no presente artigo. Para tanto, utilizou-se o ensaio do disco de difusão em ágar com inóculos de Streptococcus mutans, Streptococcus sanguinis e Escherichia coli. Periogard ${ }^{\circledR}$ mostrou atividade antibacteriana significativa contra as três cepas analisadas, quando comparada à atividade de $\mathrm{CHX} 0.12 \%(\mathrm{p}<0,05)$ e atividade similar à CHX diluída a $1 \%(\mathrm{p}>0,05)$. A presença de compostos voláteis no Periogard ${ }^{\mathbb{B}}$ foi analisada por GC-MS e observou-se que mentol, mentona, isomentol, acetato de mentila, trans-anetol e eugenol estão presentes na formulação. Deste modo, o uso de Periogard ${ }^{\circledR}$ como sinônimo de CHX 0,12\% deve ser evitado, uma vez que sua atividade se assemelha àquela da $\mathrm{CHX}$ diluída a $1 \%$.

Unitermos: Enxaguatórios bucais/avaliação. Periogard ${ }^{\circledR}$. Clorexidina. Antimicrobianos/uso buccal/ avaliação.

*Correspondence: I. B. Suffredini. Núcleo de Pesquisas em Biodiversidade. Laboratório de Extração. Universidade Paulista. Av. Paulista, 900, $1^{\circ}$. Andar - Bela Vista - 01310-100 - São Paulo - SP, Brasil. E-mail: ibsuffredini@yahoo.com.br 


\section{INTRODUCTION}

Chlorhexidine digluconate (CHX) is considered a gold standard drug in dentistry (Van Strydonc et al., 2008; Barros et al., 1998) due to its extraordinary performance against several oral micro-organisms, despite some important side effects (Sivathasan et al., 2011). For this reason, $\mathrm{CHX}$ is frequently used in almost all in house antimicrobial in vitro and in vivo assays related to oral infectious diseases (Barros et al., 1998). CHX is also part of the composition of several mouth washes, such as Periogard ${ }^{\circledR}$, and acts as the active agent. CHX has also been suggested to improve the performance and efficacy of mouth washes compared to washes that do not contain it.

Periogard ${ }^{\circledR}$ is a mouth wash that is used worldwide, and according to the manufacturer, it is composed by CHX $0.12 \%$ and some inactive components, such as water, glycerin, ethanol, polysorbate 20 , an aromatic composition with a predominant peppermint flavor, sodium saccharynate and FD\&C Blue \#1.

Attention must be paid when using Periogard ${ }^{\circledR}$ as a standard drug in place of pure chlorhexidine solutions diluted in water, for laboratory or clinical experiments. The present work aims to compare the antimicrobial activity of $0.12 \%, 1 \%$ and $2 \% \mathrm{CHX}$, anfothericin $\mathrm{B}$ and nystatin to that of Periogard ${ }^{\circledR}$ against three micro-organisms that are commonly found in the mouth. The present work also claims that the effectiveness of Periogard ${ }^{\circledR}$ might be related to a synergy between chlorhexidine and the terpenes/ phenylpropanes that are present its formula.

\section{MATERIAL AND METHODS}

\section{Drugs}

CHX 2\% was acquired (Fórmula \& Ação, São Paulo, Brazil) and diluted with sterile distilled water to obtain both $0.12 \%$ and $1 \%$ dilutions. Solutions were kept in refrigeration until use.

Periogard ${ }^{\circledR}$ was acquired from a local drugstore, and was used in its original formula, without being diluted in water. The formula without ethanol was tested in the present work.

\section{Bacteria preparation}

A frozen vial (Coastar) containing Streptococcus mutans $\mathrm{ATCC}^{\circledR} 25175^{\mathrm{TM}}$ and Streptococcus sanguinis $\mathrm{ATCC}^{\circledR} 10556^{\mathrm{TM}}$ (both from Microbiologics) suspended in broth medium containing 30\% dimethylsulfoxide (Tedia Brazil, Rio de Janeiro, Brazil) was thawed and $300 \mu \mathrm{L}$ of the suspension was surface-seeded in Brain Heart Infusion agar Petri dishes to obtain a mother-plaque. Petri dishes (J. Prolab, São José dos Pinhais, Brazil) were kept in an incubator (Fanem, Diadema, Brazil) at $36{ }^{\circ} \mathrm{C}$ for $48 \mathrm{~h}$. Then, mother-plaques presenting bacterial growth were kept in a refrigerator for up to one month. Fresh colonies were obtained weekly from the mother-plaque, and a sufficient amount of bacteria was collected from Petri dishes to prepare a suspension for further testing.

Escherichia coli $\mathrm{ATCC}^{\circledR} 25922^{\mathrm{TM}}$ Culti Loop ${ }^{\circledR}$ (Oxoid) was used to obtain mother-plaques by simply seeding a Müeller-Hinton agar Petri dish surface with lyophilized bacteria. The dish was kept in an incubator at $36^{\circ} \mathrm{C}$ for $24 \mathrm{~h}$. Fresh colonies were obtained weekly from the mother-plaque, and a sufficient amount of bacteria was collected from Petri dishes with fresh colonies to prepare a suspension for further testing.

\section{Medium}

Brain Heart Infusion agar (Oxoid) and MüellerHinton agar (Oxoid), used to test both Streptococci and Gram-negative bacteria, respectively. All media were prepared according to the manufacturer's instruction (Oxoid) and were sterilized (Fanem) before use.

\section{Antibacterial activity}

Disk diffusion assay was performed according to CLSI (formely NCCLS) standards $\left(8^{\text {th }}\right.$ edition, in Portuguese), with the following adaptations. A 0.5 MacFarland saline suspension was prepared from a fresh colony of each micro-organism. The assay was performed in sterile Brain Heart Infusion agar for both Streptococci, in Müeller-Hinton agar for E. coli, and then prepared in Petri dishes (12 cm diameter). Sterile swabs (Deltalab, Beijing, China) were used to seed micro-organisms on the medium surface. Six paper disks (Cefar Diagnostico, Sao Paulo, Brazil) measuring $6 \mathrm{~mm}$ in diameter were distributed over the inoculated medium surface. Then, $10 \mu \mathrm{L}$ of drugs were added to each disk, in triplicate. Disks were incubated at $36^{\circ} \mathrm{C}$ for $48 \mathrm{~h}$ (for Streptococci) and $24 \mathrm{~h}$ (for E. coli). Following this procedure, the diameter of growth inhibition zones was measured both horizontally and vertically using a caliper rule (Digital Caliper, Beijing, China).

\section{Separation of the non polar content of Periogard ${ }^{\circledR}$}

A non-polar fraction was partitioned from non alcoholic Periogard ${ }^{\circledR}$. Then, $100 \mathrm{~mL}$ of the mouth wash 
was transferred to a $250 \mathrm{~mL}$ funnel, and $20 \mathrm{~mL}$ of hexane (HEX, Synth, Diadema, Brazil) was added to the system. The system was stirred and put to rest up to the separation of both phases. The HEX residue was transferred to a $100 \mathrm{~mL}$ beaker. The operation was repeated two more times, and the HEX residues were combined in the beaker and left to evaporate. After that, the partition procedure was repeated with dichloromethane (DCM, Synth, Diadema, Brazil) with the remaining Periogard ${ }^{\circledR}$. The DCM residue was evaporated, and no emulsion was formed. Residue samples were closed with a cap and kept in the freezer until use. Crystals were formed during the freezing period and were then isolated by filtration, diluted in the proper solvent and sent for analysis in a gas chromatography-mass spectrometer.

\section{Gas chromatography-mass spectrometry analysis of non polar residues obtained from Periogard ${ }^{\circledR}$}

The HEX, DCM and MeOH residues were analyzed by a gas chromatographer (Shimatzu series 17A, Kyoto, Japan) coupled to a mass spectrometer (Shimatzu series QP5050A, Kyoto, Japan) (GC-MS). Non-polar residues were diluted in hexane or dichloromethane and injected into a gas chromatographer regulated to the following conditions: $1 \mu \mathrm{L}$ of the sample was injected into a BPX5 column containing non-polar 5\% phenylpolisylphenylene $(30 \mathrm{~m} \times 0.25 \mathrm{~mm}$ and a film of $0.25 \mu \mathrm{m}$ ); oven temperature of $60^{\circ} \mathrm{C}$; carrier gas of ultra-pure Helium at a flow of $2.5 \mathrm{~mL} / \mathrm{min}$; injector temperature of $280^{\circ} \mathrm{C}$; Mode Split; gradient starting at $60{ }^{\circ} \mathrm{C}$ (remaining for $2 \mathrm{~min}$ ) increasing up to $320^{\circ} \mathrm{C}$ (in $28 \mathrm{~min}$ ) at a $10^{\circ} \mathrm{C} / \mathrm{min}$ rate and remaining at $320^{\circ} \mathrm{C}$ for $6 \mathrm{~min}$, totaling $34 \mathrm{~min}$ of development. The results relating to retention time $1(7.82 \mathrm{~min})$, retention time 3 $(8.03 \mathrm{~min})$, retention time $4(8.21 \mathrm{~min})$, retention time 5 $(9.79 \mathrm{~min})$, retention time $6(9.91 \mathrm{~min})$ and retention time 7 (10.88 min) were in accordance with NIST ${ }^{\circledR}$ library.

\section{Statistical analysis}

Two-way ANOVA and Bonferroni's post test were used to analyze the efficacy of the treatments against different micro-organisms. Statistically significance among means was considered if $\mathrm{p}<0.05$.

\section{RESULTS}

The results are shown in Figure 1. According to the two-way ANOVA analysis, both treatments and micro-organism's parameters account for an extremely

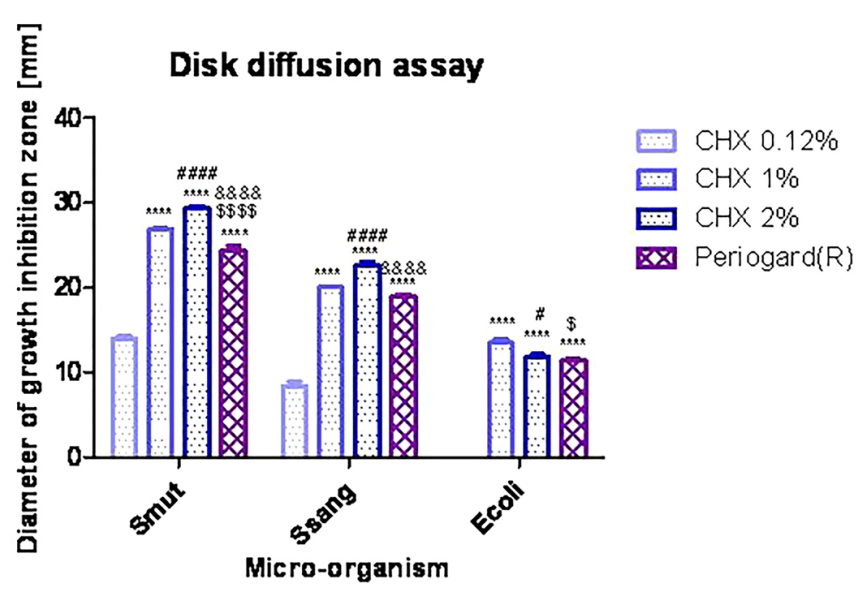

FIGURE 1 - Disk diffusion assay (measurement of growth inhibition zones, in millimeters) for standard antimicrobial drugs and Periogard ${ }^{\circledR}$ against oral-occurring micro-organisms, analyzed by two-way ANOVA and Bonferroni's post test $(p<0.05)$. Statistically significant differences were found among CHX $0.12 \%$ x CH $1 \%$, CHX $2 \%$ and Periogard ${ }^{\circledR}(*) ; C H X 1 \%$ x $\mathrm{CHX}_{2} \%(\#)$; CHX $1 \% \mathrm{x}$ and Periogard ${ }^{\circledR}(\$)$ and $\mathrm{CHX} 2 \% \mathrm{x}$ and Periogard $^{\circledR}(\&)$. CHX $=$ chlorhexidine; Smut $=$ Streptococcus mutans; Ssang= Streptococcus sanguinis; Ecoli= Escherichia coli.

significance, as follows: treatments account for $45.31 \%$ of the total variance $\left(\mathrm{F}_{(3,60)}=1092.39 ; \mathrm{p}<0.0001\right)$, and micro-organisms accounts for $52.83 \%$ of the total variance $\left(\mathrm{F}_{(3,60)}=1910.39 ; \mathrm{p}<0.0001\right)$. Thus, $\mathrm{CHX} 0.12 \%$ did not show any antibacterial activity against $E$. coli, but did show activity against $S$. mutans $(\theta=14.01 \pm 0.78 \mathrm{~mm})$ and somewhat less activity against $S$. sanguinis. CHX $1 \%$ is significantly less active than CHX $2 \%(\mathrm{P}<0.001)$ against both Streptococci and significantly less active against $E$. coli $(\mathrm{p}<0.05)$. If CHX $1 \%$ is compared with Periogard $^{\circledR}$, a significantly higher activity against $S$. mutans $(\mathrm{p}<0.001)$ and E. coli $(\mathrm{p}<0.01)$ is observed. CHX $2 \%$ is significantly more active against $S$. mutans and $S$. sanguinis $(\mathrm{p}<0.001)$ than Periogard ${ }^{\circledR}$, but it has a similar activity level against $E$. coli compared with Periogard ${ }^{\circledR}$ $(\mathrm{p}>0.05)$.

This is the classification of chlorhexidine solutions and Periogard ${ }^{\circledR}$ in relation to their anti-Streptococci activity: CHX $2 \%>$ CHX $1 \%>$ Periogard $^{\circledR}>\mathrm{CHX} 0.12 \%$. This is the classification of the standard drugs in relation to their anti-E. coli activity: CHX $1 \%>\mathrm{CHX}$ $2 \%=$ Periogard $^{\circledR}>\mathrm{CHX} 0.12 \%$.

GC-MS analysis of HEX, DCM and $\mathrm{MeOH}$ residues showed the presence of the following volatiles: menthone (retention time 1), menthol (retention time 3), isomenthol (retention time 4), menthyl acetate (retention time 5), trans-anethol (retention time 6) and eugenol (retention time 7) (Figure 2). 


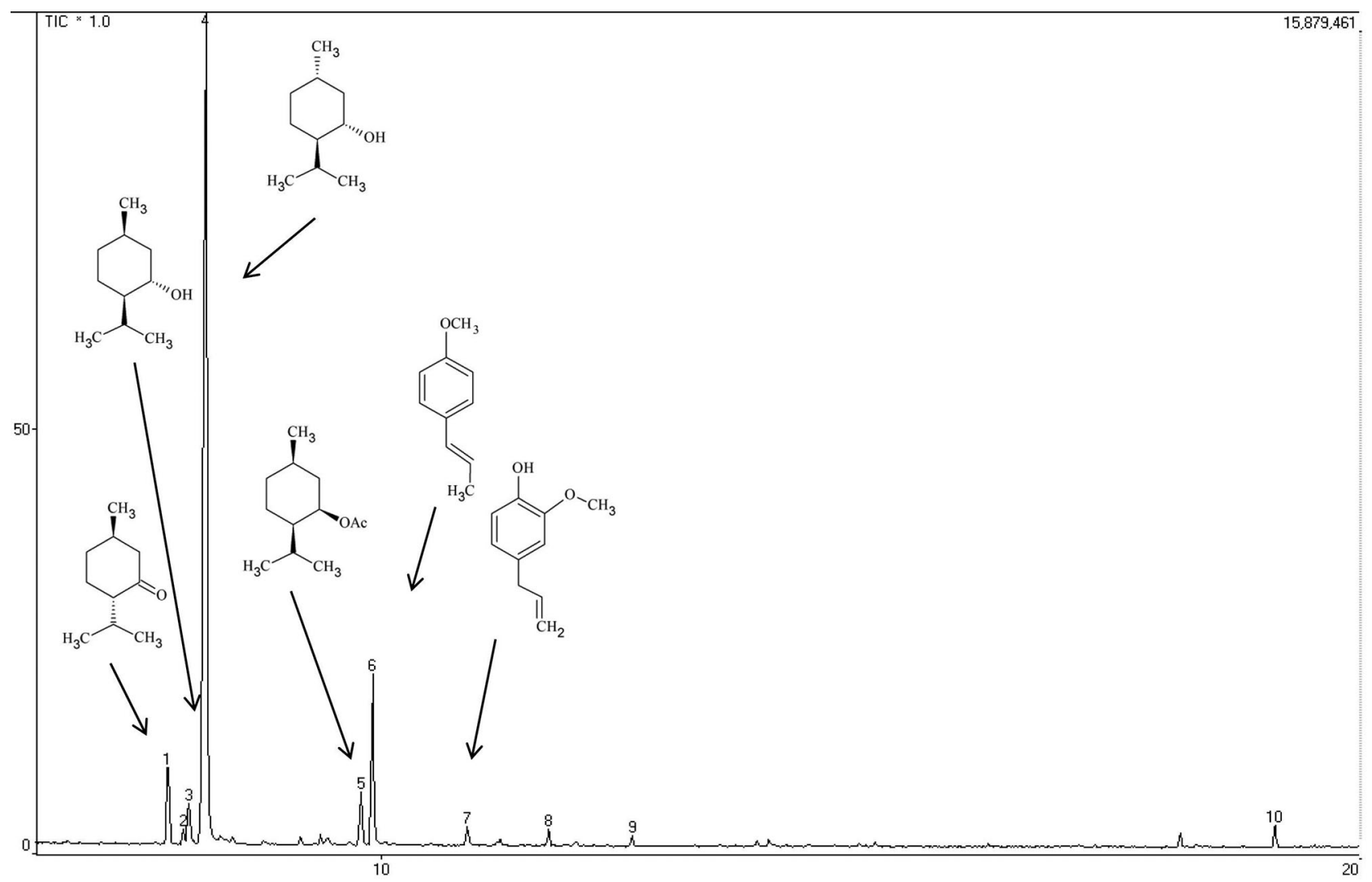

FIGURE 2 - Chromatogram obtained from gas chromatography of the non polar fractions obtained from Periogard ${ }^{\circledR}$. The determination of structures was performed with a mass spectrometer, and the results were compared with the NIST ${ }^{\circledR}$ library as follows: menthone (retention time $1=7.82 \mathrm{~min}$ ), menthol (retention time $3=8.03 \mathrm{~min}$ ), isomenthol (retention time $4=8.21 \mathrm{~min}$ ), menthyl acetate (retention time $5=9.79 \mathrm{~min}$ ), trans anethol (retention time $6=9.91 \mathrm{~min}$ ) and eugenol (retention time $7=10.88 \mathrm{~min}$ ).

\section{DISCUSSION}

The use of CHX solutions as reference drugs is widespread in laboratories and in dental clinics. The antibacterial efficacy of each specific concentration permits CHX to be used as an active substance in varnishes, gels, and solutions and for a wide range of oral infection treatments, such as caries and dental plaque control (CHX $0.12 \%, 0.2 \%$ or $1 \%$ ) (Berchier et al., 2010), mouth washes (CHX 0.2\%) (SOLÍS et al., 2011), periodontal pocket therapy (Vandekerckhove et al., 1996), gingivitis (Sheiham, 1997), plaque accumulation models (CHX 1\%) (SLOT et al., 2010) and endodontitis and cavity preparation (CHX 2\%) (Rôças, Siqueira, 2011; Gomes et al., 2009; Kontakiotis et al., 2008). A representative number of studies describe such benefits.

Periogard ${ }^{\circledR}$ is one of the most effective mouth washes recommended in dentistry, particularly due to the presence of $\mathrm{CHX}$ at concentration of $0.12 \%$. Periogard ${ }^{\circledR}$ is commonly used as a standard drug (Barrella et al., 2012; Komiyama et al., 2010; Swaty et al., 2010;
Botelho et al., 2009, Magalhães et al., 2009; Valera et al., 2009; Nascimento et al., 2008; Freitas et al., 2003) and as a synonym of $0.12 \%$ chlorhexidine digluconate. According to the manufacturer, Periogard ${ }^{\circledR}$ is a gluconate chlorhexidine solution that is prepared at a concentration of $0.12 \%$, but its free alkali, or the molecule without the gluconate ion, which is the active compound in the formulae, is found at concentrations of $0.067 \%$ in Periogard $^{\circledR}$ (Colgate-Palmolive, 2013). Thus, some authors use the concentration of $0.067 \%$ in their analysis (Felo et al., 1997). In the present manuscript, Periogard ${ }^{\circledR}$ containing $0.12 \%$ of chlorhexidine was used.

Although the antimicrobial activity of $\mathrm{CHX}$ and mouth washes has been described many times, studies reporting not only the antibacterial potency comparison between both CHX and Periogard ${ }^{\circledR}$, but also the chemical composition analysis of Periogard ${ }^{\circledR}$, are scarce. Because the misuse of CHX as synonym of Periogard ${ }^{\circledR}$ is frequent, the present work reports the results obtained from the comparison of the antibacterial analysis of $\mathrm{CHX}$ and Periogard $^{\circledR}$. The present work also describes the main volatiles extracted from the mouth wash to avoid a 
misleading analysis of the results obtained from both in vivo and in vitro experiments.

Chlorhexidine solutions, as well as Periogard ${ }^{\circledR}$, were tested against Streptococcus mutans and Streptococcus sanguinis, and against Escherichia coli. It was clearly observed that Periogard ${ }^{\circledR}$ had as much antibacterial activity as $\mathrm{CHX} 1 \%$, and was significantly more active than CHX $0.12 \%$. The presence of menthol, menthone, isomenthol, menthyl acetate, trans-anethol and eugenol may have added some antibacterial activity that might have influenced Periogard ${ }^{\circledR}$ efficacy because those terpenes/phenylpropanoids have previously shown antimicrobial activity (Li et al., 2011; Cetin et al., 2010; Lalli et al., 2010; Kotan et al., 2007; Savioli et al., 2006; Filoche et al., 2005; Harper et al., 2000).

\section{CONCLUSIONS}

According to the results obtained in the present work, all CHX solutions - except CHX 0.12\% - and Periogard ${ }^{\circledR}$ showed antimicrobial activity, but Periogard ${ }^{\circledR}$ was as active as CHX 1\%. This was perhaps due to the presence of the antibacterial active terpenes/phenylpropanoids menthol, menthone, isomenthol, menthyl acetate, transanethol and eugenol.

\section{ACKNOWLEDGEMENTS}

Authors thank FAPESP for grant \# 2008/58706-8.

\section{REFERENCES}

BARRELLA, G.E.; SUFFREDINI, I.B.; RIBEIRO, F.V.; CIRANO, F.R.; PIMENTEL, S.P. Evaluation of the effect of the organic extract obtained from Ipomoea alba L. on experimental periodontitis. Braz. Oral Res. v. 26, n.2, p.158-164, 2012.

BARROS, V.M.R.; ITO, I.Y.; AZEVEDO, R.V.P.; MORELLO, D.; ROSATELI, p.A. Estudo comparativo da eficiência de três métodos de anti-sepsia intrabucal na redução do número de estreptococos do sulco gengival. Rev. Odontol. Univ. São Paulo, v.12, n.3, p.201-206, 1998.

BERCHIER, C.E.; SLOT, D.E.; VAN DER WEIJDEN, G.A. The efficacy of $0.12 \%$ chlorhexidine mouthrinse compared with $0.2 \%$ on plaque accumulation and periodontal parameters: a systematic review. J. Clin. Periodontol., v.37, n.9, p.829-839, 2010.
BOTELHO, M.A.; DOS SANTOS, R.A.; MARTINS, J.G.; CARVALHO, C.O.; PAZ, M.C.; AZENHA, C.; RUELA, R.S.; QUEIROZ, D.B.; RUELA, W.S.; MARINHO, G.; RUELA, F.I. Comparative effect of an essential oil mouthrinse on plaque, gingivitis and salivary Streptococcus mutans levels: a double blind randomized study. Phytother. Res., v.23, n.9, p.1214-1219, 2009.

CETIN, B.; OZER, H.; CAKIR, A.; POLAT, T.; DURSUN, A.; METE, E.; OZTÜRK, E.; EKINCI, M. Antimicrobial activities of essential oil and hexane extract of Florence fennel [Foeniculum vulgare var. azoricum (Mill.) Thell.] against foodborne microorganisms. J. Med. Food, v.13, n.1, p.196-204, 2010.

COLGATE-PALMOLIVE COMPANY. Brasil. Available at: $<$ www.colgateprofissional.com.br/produtos/Enxaguatoriobucal-Colgate-PerioGard/especificacoes $>$. Accessed 09 May 2013.

FELO, A.; SHIBLY, O.; CIANCIO, S.G.; LAUCIELLO, F.R.; $\mathrm{HO}, \mathrm{A}$. Effects of subgingival chlorhexidine irrigation on peri-implant maintenance. Am. J. Dent., v.10, n.2, p.107110, 1997.

FILOCHE, S.K.; SOMA, K.; SISSONS, C.H. Antimicrobial effects of essential oils in combination with chlorhexidine digluconate. Oral Microbiol. Immunol., v.20, n.4, p.221225, 2005.

FREITAS, C.S.; DINIZ, H.F.O.; GOMES, J.B.; SINISTERRA, R.D.; CORTES, M.E. Evaluation of the substantivity of chlorhexidine in association with sodium fluoride in vitro. Pesq. Odontol. Bras., v.17, n.1, p.78-81, 2003.

GOMES, B.P.; MARTINHO, F.C.; VIANNA, M.E. Comparison of $2.5 \%$ sodium hypochlorite and $2 \%$ chlorhexidine gel on oral bacterial lipopolysaccharide reduction from primarily infected root canals. J. Endod., v.35, n.10, p.1350-1353, 2009.

HARPER, D.S.; BROGDON, C.L.; WU, M.M.; EPELLE, U. A rapid method for evaluating microbicidal activity of dentifrice formulations against salivary bacteria ex vivo. $J$. Clin. Dent., v.11, n.4, p.89-93, 2000.

KOMIYAMA, E.Y.; BACK-BRITO, G.N.; BALDUCCI, I.; KOGA-ITO, C.Y. Evaluation of alternative methods for the disinfection of toothbrushes. Braz. Oral Res., v.24, n.1, p.28-33, 2010. 
KONTAKIOTIS, E.G.; TSATSOULIS, I.N.; PAPANAKOU, S.I.; TZANETAKIS, G.N. Effect of $2 \%$ chlorhexidine gel mixed with calcium hydroxide as an intracanal medication on sealing ability of permanent root canal filling: a 6-month follow-up. J. Endod., v.34, n.7, p.866-870, 2008.

KOTAN, R.; KORDALI, S.; CAKIR, A. Screening of antibacterial activities of twenty-one oxygenated monoterpenes. Z. Naturforsch. C, v.62, n.7-8, p.507-513, 2007.

LALLI, J.Y.; VILJOEN, A.M.; VAN VUUREN, S.F. Potential interaction between the volatile and non-volatile fractions on the in vitro antimicrobial activity of three South African Pelargonium (Geraniaceae) species. Nat. Prod. Commun., v.5, n.9, p.1395-1400, 2010.

LI, J.; DONG, J.; QIU, J.Z.; WANG, J.F.; LUO, M.J.; LI, H.E.; LENG, B.F.; REN, W. Z.; DENG, X.M. Peppermint oil decreases the production of virulence-associated exoproteins by Staphylococcus aureus. Molecules, v.16, n.2, p.1642-1654, 2011.

MAGALHÃES, A.C.; WIEGAND, A.; RIOS, D.; HANNAS, A.; ATTIN, T.; BUZALAF, M.A. Chlorhexidine and green tea extract reduce dentin erosion and abrasion in situ. $J$. Dent., v.37, n.12, p.994-998, 2009.

NASCIMENTO, A.P.; TANOMARU, J.M.G.; MATOBAJUNIOR, F.; WATANABE, E.; TANOMARU-FILHO, M.; ITO, I.Y. Maximum inhibitory dilution of mouthwashes containing chlorhexidine and polyhexamethylene biguanide against salivary staphylococcus aureus. J. Appl. Oral Sci., v.16, n.5, p.336-339, 2008.

RÔÇAS, I.N.; SIQUEIRA, J.F.Jr. Comparison of the in vivo antimicrobial effectiveness of sodium hypochlorite and chlorhexidine used as root canal irrigants: a molecular microbiology study. J. Endod., v.37, n.2, p.143-150, 2011.

SAVIOLI, R.N.; PECORA, J.D.; MIAN, H.; ITO, I.Y. Evaluation of the antimicrobial activity of each component in Grossman's sealer. Braz. Oral Res., v.20, n.2, p.127-131, 2006.

SHEIHAM, A. Is the chemical prevention of gingivitis necessary to prevent severe periodontitis? Periodontology 2000, v.15, p.15-24, 1997.
SLOT, D.E.; ROSEMA, N.A.; HENNEQUIN-HOENDERDOS, N.L.; VERSTEEG, p.A.; VAN DER VELDEN, U.; VAN DER WEIJDEN, G.A. The effect of $1 \%$ chlorhexidine gel and $0.12 \%$ dentifrice gel on plaque accumulation: a 3-day non-brushing model. Int. J. Dent. Hyg., v.8, n.4, p.294-300, 2010.

SIVATHASAN, N.; CHAKHABARTY, K. H. Skin cleansers: the risk of chlorhexidine. J. Clin. Pharmacol., v.51, n.5, p.785-785, 2011.

SOLÍS, C.; SANTOS, A.; NART, J.; VIOLANT, D. 0.2\% chlorhexidine mouthwash with an antidiscoloration system versus $0.2 \%$ chlorhexidine mouthwash: a prospective clinical comparative study. J. Periodontol., v.82, n.1, p.8085, 2011.

SWATY, J.; VINEETA, N.; VIJAY, S. An in vitro study of antibacterial effect of calcium hydroxide and chlorhexidine on Enterococcus faecalis. Indian J. Dental Res., v.21, n.4, p.512-514, 2010.

VALERA, M.C.; DA SILVA, K.C.G.; MAEKAWA, L.E.; CARVALHO, C.A.T.; KOGA-ITO, C.Y.; CAMARGO, C.H.R.; SILVA E LIMA, R. Antimicrobial activity of sodium hypochlorite associated with intracanal medication for Candida albicans and Enterococcus faecalis inoculated in root canals. J. Appl. Oral Sci., v.17, n.6, p.555-559, 2009.

VAN STRYDONC, D.A.; TIMMERMAN, M.F.; VAN DER VELDEN, U.; VAN DER WEIJDEN, F. Clinical efficacy of a chlorhexidine-delivering toothbrush. J. Clin. Periodontol., v.35, n.7, p.584-590, 2008 .

VANDEKERCKHOVE, B.N.; BOLLEN, C.M.; DEKEYSER, C.; DARIUS, P.; QUIRYNEN, M. Full-versus partial-mouth disinfection in the treatment of periodontal infections. Longterm clinical observations of a pilot study. J. Periodontol., v.67, n.12, p.1251-1259, 1996.

Received for publication on $25^{\text {th }}$ March 2014 Accepted for publication on $02^{\text {nd }}$ December 2014 